\title{
ANALISIS EFISIENSI EKONOMI USAHATANI UBI JALAR DI KECAMATAN AMPEK ANGKEK, KABUPATEN AGAM, SUMATERA BARAT
}

\author{
Angelia Leovita \\ Dosen Program Studi Agribisnis \\ Universitas Tamansiswa Padang \\ Email : Angelialeovita41@gmail.com
}

\begin{abstract}
Abstrak
Produksi dari suatu komoditi ditentukan oleh pengalokasian input produksi yang efisien. Efisiensi dipengaruhi kombinasi dalam megunakan input-input produksi, faktor sosial ekonomi petani dan faktor diluar kendali petani. Tujuan penelitian untuk mengetahui faktor yang mempengaruhi produksi, efisiensi teknis, alokatif dan ekonomi. Data diperoleh dengan melakukan wawancara dengan 40 orang petani responden di dua Nagari/Desa di Kecamatan Ampek Angkek, Kabupaten Agam, Sumatera Barat. Data dianalisis dengan menggunakan dua alat analisis, yaitu produksi Stochastic Frontier dan fungsi biaya dual. Penelitian menunjukkan bahwa variabel jumlah bibit, pupuk organik, jumlah tenaga kerja dalam keluarga dan luar keluarga berpengaruh pada taraf $1 \%$. Sedangkan variabel jumlah pupuk anorganik berpengaruh pada taraf $10 \%$. Berdasarkan nilai rata-rata efisiensi teknis yaitu 0,85 , telah efisien. Efisiensi alokatif sudah efisien dengan nilai rata-rata 0,79 dan efisiensi ekonomi nilai rata-rata 0,67 belum efisien.
\end{abstract}

Kata kunci : produksi ubi jalar, efisiensi alokatif, efisiensi ekonomi, stochastic frontier

\section{PENDAHULUAN}

Pertumbuhan penduduk Indonesia melaju dengan cepat, yakni $1,49 \%$ pada periode 1990-2000 dan untuk tahun 2012 sebesar 1,3\%. Tingginya laju pertumbuhan penduduk, mengindikasikan bahwa kepadatan penduduk semakin tinggi. Permasalahan besarnya penduduk berkaitan langsung dengan masalah pangan. Kebutuhan pangan utama penduduk indonesia adalah beras. Sekitar $90 \%$ beras merupakan kebutuhan pangan pokok. Konsumsi beras Indonesia pada tahun $2002107,71 \mathrm{~kg} / \mathrm{kapita} / \mathrm{tahun}$ menurun menjadi 97,65 $\mathrm{kg} / \mathrm{kapita} / \mathrm{tahun}$ tahun 2012 (PUSDATIN, 2013).

Diversifikasi pangan dapat menjadi alternatif untuk permasalahan tersebut. Kebijakan yang dilakukan dalam diversifikasi pangan dapat dilakukan melalui (1) pengembangan konsumsi pangan karbohidrat yang beragam, (2) pengembangan dan peningkatan daya tarik pangan karbohidrat non beras dab (3) pengembangan produk dan mutu produk pangan karbohidrat non beras yang bergizi tinggi dan memungkinkan untuk dikembangkan (Nurmalina, 2008).

Ubi jalar merupakan pangan sebagai jenis pangan sebagai pangan alternatif selain beras adalah Ubi jalar mempunyai keunggulan lebih dari aneka umbi lainnya. Ubi jalar kaya akan manfaat antara: memiliki nutrisi yang dibutuhkan oleh dalam 100 gramnya tubuh seperti: (1) kalori $123 \mathrm{kal}$, (2) protein 1.8 gram, (3) lemak 0.7 gram, (4) karbohidrat 27.9 gram, (5) mineral 1.1 gram, (6) kalium 49 mgram, (7) vitamin A 7700 SI dan vitamin C 22 mgram. Terdapat zat antioksidan untuk mencegah pembentukan sel radikal bebas (kanker) maupun betakarotin, zat yang sangat dibutuhkan untuk kesehatan mata. Mengingat ubi jalar 
mempunyai banyak manfaat dan digunakan sebagai pangan lokal, maka pemilihan ubi jalar untuk alternatif pangan perlu mendapat perhatian dan dikembangkan serta diperluas pertanamannya untuk mendukung kemandirian pangan (Direktorat Jenderal Tanaman Pangan, 2013).

Di Indonesia terdapat lima provinsi produksi ubi jalar terbesar. Pada Tabel 1 dapat dilihat bahwa provinsi dengan luas lahan terbesar adalah Papua. Produksi ubi jalar terbanyak terdapat pada provinsi Jawa Barat. Sedangan untuk produktivitas ubi jalar tertinggi ada pada provinsi Sumatera Barat.

Tabel 1. Luas Panen, Produktivitas dan Produksi Ubi Jalar di Sepuluh Provinsi di Indonesia Tahun 2015

\begin{tabular}{|l|c|c|c|}
\hline \multicolumn{1}{|c|}{ Provinsi } & Luas Panen $(\mathrm{Ha})$ & Produksi (ton) & Produktivitas (ton/ha) \\
\hline Jawa Barat & 23.154 & 456.176 & 19.40 \\
Papua & 36.091 & 446.925 & 12.38 \\
Jawa Timur & 12.782 & 350.516 & 27.40 \\
Sumatera Barat & 5.127 & 160.992 & 31.40 \\
Sumatera Utara & 8.952 & 122.362 & 13.66 \\
\hline
\end{tabular}

Sumber : Badan Pusat Statistik 2017

\section{Perumusan Masalah}

Sumatera Barat memliki produktivitas tinggi, namun pada beberapa daerah sentra ubi jalar di Sumatera Barat memiliki Produktivitas yang rendah. Salah satu daerah sentra ubi jalar adalah kecamatan Ampek Angkek. Produktivitas ubi jalar di kecamatan Ampek Angkek adalah 16,23 ton/ha, masih sangat rendah jika dibandingkan dengan produtivitas ubi jalar Sumatera Barat. Petani belum mampu mengalokasikan dengan tepat faktor-faktor produksi yang ada dalam proses usahataninya sehingga akan berpengaruh kepada efisiensi alokati dan ekonomi.

\section{METODE PENELITIAN}

\section{Lokasi dan Waktu Penelitian}

Pemilihan lokasi penelitian dilakukan degan Purposive dengan pertimbangan merupakan wilayah sentra produksi ubi jalar di Sumatera Barat.

\section{Jenis dan Sumber Data}

Jenis data yang digunakan adalah cross section. Sumber data berupa data sekunder dan data primer (melalui wawancara dengan petani). Data sekunder diperoleh dari instansi yang terkait dengan penelitian baik di tingkat pusat maupun daerah.

\section{Metode Penarikan Contoh}

Jumlah petani contoh yang digunakan 40 orang. Petani contoh berasal dari 2 desa yang merupakan nagari/desa yang memiliki produksi ubi jalar terbesar di kecamatan Ampek Angkek. Pengambilan petani contoh dilakukan dengan teknik snowball sampling. Sehingga penentuan petani contoh berdasarkan informasi petani contoh sebelumnya.

\section{Analisi Data}

Analisis Fungsi Produksi Stochastic Frontier

Data dianalisis dengan fungsi produksi stochastic frontier dan fungsi biaya dual. 
Analisis fungsi stochastic frontier mengukur efisiensi teknis dari usahatani ubi jalar dan faktor-faktor yang mempengaruhi efisiensi teknis.

$\mathrm{Ln} Y=\beta 0+\beta 1 \ln X 1+\beta 2 \ln \mathrm{X} 2+\beta 3 \ln \mathrm{X} 3+\beta 4 \ln \mathrm{X} 4+\beta 5 \ln \mathrm{X} 5+\mathrm{vi}-\mathrm{ui}$

Dengan $Y=$ hasil produksi ubi jalar $(\mathrm{kg}), \mathrm{X} 1=$ jumlah bibit (buah), $\mathrm{X} 2=$ jumlah pupuk organic $(\mathrm{kg}), \mathrm{X} 3=$ jumlah pupuk anorganik $(\mathrm{kg}), \mathrm{X} 4=$ jumlah tenaga kerja dalam keluarga $(\mathrm{HKP}), \mathrm{X} 5=$ jumlah tenaga kerja luar keluarga (HKP) dan vi - ui= error term.

Analisis efisiensi alokatif dan ekonomi

Efisiensi alokatif dan ekonomi dapat diukur dengan menurunkan fungsi biaya dual dari fungsi produksi Cobb-Douglass. Dengan meminimimkan fungsi biaya input dengan kendala fungsi produksi pada persamaan (1) sehingga fungsi biaya dual frontier adalah sebagai berikut: $\operatorname{Ln} C=\beta 0+\beta 1 \ln Y+\beta 2 \ln P 1+\beta 3 \ln P 2+\beta 4 \ln P 3+\beta 5 \ln P 4+\beta 6 \ln P 5$ dengan $\mathrm{C}=$ biaya produksi ubi jalar $(\mathrm{Rp}), \mathrm{Y}=$ jumlah produksi ubi jalar $(\mathrm{kg}), \mathrm{P} 1=$ harga ratarata bibit ubi jalar (Rp/bibit), $\mathrm{P} 2=$ harga rata-rata pupuk organik $(\mathrm{Rp}), \mathrm{P} 3=$ harga rata-rata pupuk anorganik (Rp), $\mathrm{P} 4=$ biaya/upah tenaga kerja dalam keluarga HKP (Rp), P5= biaya/upah tenaga kerja luar keluarga $\operatorname{HKP}(\mathrm{Rp}), \beta_{0}, \beta_{1}, \beta_{2}, \beta_{3}, \beta_{4}, \beta_{5}=$ parameter estimasi Efisiensi ekonomi didefinisikan sebagai rasio total biaya produksi minimum yang diobservasi (C*) dengan total biaya produksi actual (C) (Jondrow et al. 1982). Persamaanya sebagai berikut

$\mathrm{EE}=\frac{C^{*}}{C}=\frac{E\left(C_{i} \mid u_{i}=0, Y_{i}, P_{i}\right)}{E\left(C_{i} \mid u_{i}, Y_{i}, P_{i}\right)}$

Dimana EE bernilai $0 \leq \mathrm{EE} \leq 1$. Efisiensi ekonomi (EE) merupakan gabungan dari efisiensi teknis (ET) dan efisiensi alokatif (AE), sehingga AE dapat diperoleh sebagai berikut:

$\mathrm{AE}=\frac{\mathrm{EE}}{\mathrm{TE}}$

\section{HASIL DAN PEMBAHASAN}

\section{Analisis Fungsi produksi stochastic frontier}

Fungsi produksi stochastic frontier usahatani ubi jalar dianalisis dengan menggunakan metode MLE dengan frontier 4,1. Hasil pendugaan model produksi stochastic frontier dijadikan dasar untuk mengukur efisiensi alokatif dan efisiensi ekonomi dengan menurunkan fungsi biaya dual. Hasil pendugaan model produksi frontier ubi jalar di kecamatan Ampek Angkek adalah sebagai berikut:

$$
\mathrm{Y}=1,75 X_{1}^{0,17} X_{2}^{0,38} X_{3}^{0,13} X_{4}^{0,16} X_{5}^{0,37}
$$

Tabel 2 menunjukkan hasil pendugaan model produksi Cobb-Douglas Stochastic Frontier usahatani ubi jalar menggunakan metode MLE di kecamatan Ampek Angkek. Variabel yang berpengaruh nyata pada $a=1 \%$ terhadap produksi batas (frontier) ubi jalar adalah variabel jumlah bibit ubi jalar (X1), jumlah pupuk organik (X2), jumlah tenaga kerja dalam keluarga (X4) dan jumlah tenaga kerja luar keluarga (X5). Sedangkan jumlah pupuk anorganik (X3) berpengaruh nyata pada a=10\%. Nilai gamma $(\gamma)$ pada adalah sebesar 0,98. Artinya bahwa sebesar $98 \%$ dari variasi hasil diantara petani karena perbedaan efisiensi teknis sementara sisanya $2 \%$ karena efek-efek stochastic diluar model, seperti pengaruh cuaca atau iklim, serangan hama penyakit dan bencana alam. 
Tabel 2. Hasil Dugaan Model Produksi Cobb-Douglas Stochastic Frontier Menggunakan Metode MLE

\begin{tabular}{|l|c|c|}
\hline \multicolumn{1}{|c|}{ Variabel } & Koefisien & t-ratio \\
\hline Konstanta & 1,75 & 3,54 \\
Jumlah bibit ubi jalar $\left(\mathrm{X}_{1}\right)$ & 0,17 & $4,04^{\mathrm{a}}$ \\
Jumlah pupuk organik $\left(\mathrm{X}_{2}\right)$ & 0,38 & $3,36^{\mathrm{a}}$ \\
Jumlah pupuk anorganik $\left(\mathrm{X}_{3}\right)$ & 0,13 & $1,71^{\mathrm{b}}$ \\
Jumlah tenaga kerja dalam keluarga & 0,16 & $2,85^{\mathrm{a}}$ \\
$\left(\mathrm{X}_{4}\right)$ & & \\
Jumlah tenaga kerja luar keluarga $\left(\mathrm{X}_{5}\right)$ & 0,37 & $2,85^{\mathrm{a}}$ \\
Gamma & 0,98 & 0,52 \\
Log-likehood function OLS & 29,93 & \\
Log-likehood function MLE & 36,14 & \\
LR test of the one $=$ sided error & 12,42 & \\
\hline
\end{tabular}

a berpengaruh nyata pada a 0,01

b berpengaruh nyata pada a 0,10

Hasil pendugaan Generalized Likelihood Ratio (LR) dari model produksi ubi jalar stochastic frontier petani sampel adalah 12,42. Nilai tersebut lebih besar dari tabel Kodde dan Palm sebesar 10,37 yang nyata pada $a=5 \%$. Hal ini menunjukkan secara kuat menolak hipotesis bahwa tidak ada efek inefisiensi, menerangkan aktivitas usahatani ubi jalar dipengaruhi oleh efisiesnsi teknis.

Variabel pupuk organik (X2) berpengaruh nyata pada taraf $1 \%$ dan memiliki nilai koefisien atau nilai elastisitas paling besar yaitu sebesar 0,38, artinya bahwa setiap penambahan input pupuk organik sebesar 1 persen dengan jumlah input lain tetap akan meningkatkan produksi sebesar 3,8 persen. Peningkatan produksi yang tinggi dengan adanya penambahan input pupuk organik karena jumlah penggunaannya masih sedikit. Pupuk organik yang digunakan per hektar sebesar 9.240,31 kilogram sedangkan anjuran penyuluh berkisar antara 15 sampai 20 ton per hektar.

Variabel pupuk anorganik (X3) berpengaruh nyata pada taraf 10 persen dan memiliki nilai koefisien atau elastisitas terkcil yaitu sebesar 0,13 , artinya bahwa dengan menaikkan jumlah pupuk anorganik sebesar 10 persen dengan jumlah input lainnya tetap,akan meningkatkan produksi sebesar 1,3 persen. Nilai elastisitas yang kecil mengindikasikan bahwa penggunaan pupuk anorganik pada lokasi penelitian telah sesuai. Penggunaan pupuk anorganik disini adalah pupuk Urea, pupuk Phonska dan pupuk NPK. Pupuk yang digunakan per hektar untuk masing-masing jenis pupuk adalah 91,68 kilogram, 116,07 kilogram dan 20,15 kilogram.

Pada lokasi penelitian seluruh petani responden menggunakan pupuk Urea dan Phonska. Namun hanya beberapa petani yang hanya menggunkan pupuk NPK. Hal ini disebabkan karena, petani tersebut tidak melakukan rotasi tanaman seperti petani lainnya.. informasi dari penyuluh setempat, jika lahan digunakan secara terus menerus untuk bertanam ubi jalar maka hasil yang didapatkan buahnya lebih kecil. Sehingga harus ada penambahan pupuk untuk perbaikan pertumbuhan tanaman ubi jalar.

Analisis efisiensi teknis Efisiensi teknis dianalisis dengan menggunakan model 
produksi stochastic frontier. Nilai efisiensi teknis sudah efisien jika besar dari 0,7 (Kusnadi et al, 2011). Dengan melihat sebaran nilai efisiensi teknis per petani, 37 orang petani atau sebesar $92,5 \%$ dengan nilai efisiensi teknis $=0,7$, sedangkan 3 orang petani atau sebesar 7,5\% berada dibawah nilai 0,7 sehingga sebagian besar usahatani ubi jalar yang diusahakan telah efisien secara teknis (Tabel 3). Faktor-faktor yang mempengaruhi tingkat inefisiensi teknis petani diperoleh dari hasil penggunaan model efek inefisiensi teknis dan fungsi produksi stochastic frontier.

Hasil menunjukkan bahwa umur, jumlah tanggungan dan dummy kepemilikan lahan berpengaruh positif. Artinya umur petani yang semakin bertambah, jumlah tanggungan yang banyak dan status lahan milik sendiri akan menambah inefisiensi. Variabel tingkat pendidikan, pengalaman berusahatani, dummy anggota kelompok tani dan jenis varietas bertanda negatif, artinya bahwa akan menurunkan inefisiensi.

Diantara semua variabel hanya ada tiga variabel yang berpengaruh secara nyata pada taraf $10 \%$ dan $20 \%$. Variabel umur berpengaruh positif dan nyata terhadap inefisiensi. Semakin tinggi umur maka inefisiensi teknis meningkat karena kondisi secara fisik semakin menurun. Artinya bahwa petani yang berumur muda akan lebih efisien dalam berusahatani. Hasil penelitian ini sejalan dengan Idiong (2007), Okaye (2008) dan Ohajianya et al. (2014). Dummy variabel anggota kelompok tani memiliki koefisien negatif dan berpengaruh nyata.Ini mengartikan bahwa petani yang ikut dalam kelompok tani akan lebih efisien dibandingkan dengan yang tidak tergabung dalam kelompok tani. Menurut Haryani (2009), petani yang tergabung dan aktif dalam kelompok tani akan dapat (1) meningkatkan pengetahuan melalui pendidikan non formal, (2) meningkatkan kemampuan manajerial, (3) meningkatkan aksesibilitas terhadap teknologi dan inovasi baru dan (4) meningkatkan aksesibilitas terhadap bantuan kredit dan bantuan lainnya karena disalurkan melalui kelompok tani.

Tabel 3. Sebaran Nilai Efisiensi Teknis

\begin{tabular}{|c|c|c|}
\hline Sebaran Efisiensi Teknis & Jumlah (orang) & Persen (\%) \\
\hline$<0,50$ & 0 & 0,00 \\
$0,50-0,59$ & 1 & 2,50 \\
$0,60-0,69$ & 2 & 5,00 \\
$0,70-0,79$ & 7 & 17,50 \\
$0,80-0,89$ & 16 & 40,00 \\
$0,90-0,99$ & 14 & 35,00 \\
\hline Jumlah & 40 & 100,00 \\
\hline Rata-rata & & \\
Maksimum & \multicolumn{2}{|c|}{0,85} \\
Minimum & 0,98 \\
\hline
\end{tabular}

Analisis Efisiensi Alokatif Tingkat efisiensi alokatif pada penelitian ini dilihat dari sisi input produksi berdasarkan pada harga input yang berlaku ditingkat petani. 
Tabel 4. Sebaran Nilai Efisiensi Alokatif

\begin{tabular}{|l|c|c|}
\hline \multirow{2}{*}{ Sebaran } & \multicolumn{2}{|c|}{ Nilai } \\
\cline { 2 - 3 } Efisiensi & Jumlah & Persen (\%) \\
\hline$>0,50$ & 0 & 0,00 \\
$0,50-0,59$ & 0 & 0,00 \\
$0,60-0,69$ & 1 & 2,50 \\
$0,70-0,79$ & 21 & 52,50 \\
$0,80-0,89$ & 16 & 40,00 \\
$0,90-0,99$ & 2 & 5,00 \\
\hline Jumlah & 40 & 100,00 \\
\hline Rata-rata & 0,79 & \\
Maksimum & 0,94 & \\
Minimum & 0,67 & \\
\hline
\end{tabular}

Analisis efisiensi alokatif diperoleh dari hasil bagi antara efisiensi ekonomi (EE) dengan efisiensi teknis (ET). Tabel 4 menunjukkan bahwa nilai rata-rata efisiensi alokatif adalah sebesar 0,79. Petani responden memiliki efisiensi alokatif maksimal sebesar 0,94 dan minimum sebesar 0,67. Sebaran efisiensi alokatif petani responden yang sudah efisien adalah sebesar $97,5 \%$, artinya $97,5 \%$ petani responden mampu mengalokasikan inputnya pada masing-masing harga input sehingga membuat biaya minimum. Jika rata-rata petani dapat mencapai tingkat efisiensi alokatif yang paling tinggi, maka petani akan menghemat biaya sebesar $16 \%$ atau $1-(0,79 / 0,94)$. Sedangkan petani paling tidak efisien akan menghemat biaya sebesar $29 \%$ atau $1-(0,67 / 0,94)$.

Efisiensi Ekonomi Petani Ubi Jalar Efisiensi ekonomi merupakan gabungan atau kombinasi efisiensi teknis dengan efisiensi alokatif. Tingkat efisiensi ekonomi dianalisis dengan fungsi biaya dual. Pada Tabel 5 menunjukkan bahwa nilai rata-rata efisiensi ekonomi pada sebesar 0,67 dengan kisaran nilai efisiensi ekonomi sebesar 0,47 sampai dengan 0,83. Berdasarkan nilai efisiensi ekonomi tersebut menunjukkan bahwa secara ekonomi belum efisien. Petani responden yang sudah efisien sebesar 35\% dan 65\% belum efisien secara ekonomi. Selanjutnya petani responden memiliki efisiensi ekonomi yang maksimal sebesar 0,83 dan minimum sebesar 0,47 . jika petani ingin dapat mencapai efisiensi ekonomi paling maksimum maka harus menghemat biaya sebesar $20 \%$ atau $1-(0,67 / 0,83)$ dan untuk petani paling tidak efisien akan mampu menghemat biaya sebesar $44 \%$ atau $1-(0,47 / 0,83)$ jika dapat mencapai tingkat efisiensi ekonomi paling tinggi.

Tabel 5. Sebaran Nilai Efisiensi Ekonomi

\begin{tabular}{|c|c|c|}
\hline Sebaran & \multicolumn{2}{|c|}{ Nilai } \\
\cline { 2 - 3 } Efisiensi & Jumlah & Persen $(\%)$ \\
\hline$>0,50$ & 1 & 2,50 \\
$0,50-0,59$ & 6 & 15,00 \\
$0,60-0,69$ & 19 & 47,50 \\
$0,70-0,79$ & 11 & 27,50 \\
$0,80-0,89$ & 3 & 7,50 \\
$0,90-0,99$ & 0 & 0,00 \\
\hline
\end{tabular}




\begin{tabular}{|l|r|c|}
\hline Jumlah & 40 & 100,00 \\
\hline Rata-rata & 0,67 & \\
Maksimum & 0,83 & \\
Minimum & 0,47 & \\
\hline
\end{tabular}

Tingkat efisiensi ekonomi yang masih rendah, disebabkan oleh masih terdapat faktor atau input produksi yang harganya masih mahal. Seperti biaya tenaga kerja sebesar Rp 65.843,48, dimana pada usahatani ubi jalar ini masih sarat dengan tenaga kerja. Selain penggunaan bibit yang digunakan jumlah banyak dengan harga bibit relatif mahal.

\section{Kesimpulan}

Berdasarkan hasil penelitian maka dapat diambil kesimpulan:

1. Variabel-variabel yang ditemukan signifikan berpengaruh secara statistik $\mathrm{a}=1 \%$ adalah variabel jumlah bibit, jumlah pupuk organik jumlah tenaga kerja dalam keluarga dan jumlah tenaga luar keluarga. Sedangkan jumlah pupuk anorganik signifikan berpengaruh secara statistik pada $\mathrm{a}=10 \%$.

2. Tingkat pencapaian efisiensi teknis (TE) usahatani ubi jalar tergolong tinggi. Hal ini mengindikasikan bahwa usahatani ubi jalar di lokasi penelitian sudah efisien dengan efisiensi teknis rata-rata 0,85 .

3. Tingkat pencapaian efisiensi alokatif (AE) usahatani ubi jalar sudah mencapai efisien dengan nilai rata-rata efisiensi alokatif 0,79 .

4. Pencapaian efisiensi ekonomi (EE) usahatani ubi jalar tergolong rendah. Hal ini menunjukkan bahwa usahatani ubi jalar di lokasi penelitian belum efisien dengan nilai rata-rata efisiensi ekonomi 0,67 .

5. Faktor-faktor yang ditemukan signifikan berpengaruh secara statistik terhadap inefisiensi teknis pada $\mathrm{a}=10 \%$ adalah keanggotaan dalam kelompok yang bertanda negatif. Artinya, petani yang tergabung dan aktif dalam kelompok tani akan menurunkan inefisiensi atau menuju efisien. Faktor yang signifikan berpengaruh secara statistik terhadap inefisiensi teknis pada $a=20 \%$ adalah umur dan status kepemilikan lahan. Koefisien umur adalah positif, artinya bertambah umur maka bertambah inefisien usahatani. Status kepemilikan lahan berkoefisien positif, artinya petani nonpemilik atau penyewa akan lebih efisien dalam usahataninya. Hal ini disebabkan karena petani penyewa mempunyai tanggung jawab untuk memperoleh output yang maksimal dan keuntungan yang tinggi untuk membayar sewa lahan.

\section{Datar Pustaka}

Coelli, TJ. 1998. A Guide to Frontier Version 4.1: A Computer Program fo Stochastic Frontier Production and Cost Function Estimation. Centre for Efficiency and Productivity Analysis (CEPA) Working Papers. Armidale (AU): Department of Econometrics. University of New England.

[BPS] Badan Pusat Statistik. 2017. Statistik Indonesia. Jakarta (ID): Badan Pusat Statistik. Direktorat Jenderal Tanaman Pangan. 2013. Pedoman Teknis Pengelolaan Produksi Ubi Jalar dan Aneka Umbi. Jakarta (ID): Direktorat Jenderal Tanaman Pangan. 
Haryani, D. 2009. Analisis Efisiensi Usahatani Padi Sawah Pada Program Pengelolaan Tanaman dan Sumberdaya Terpadu di Kabupaten Serang, Provinsi Banten. Tesis. Sekolah Pascasarjana, Institut Pertanian Bogor, Bogor.

Idiong, I.C. 2007. Estimation of Farm Level Technical Efficiency in Smallscale Swamp Rice Production in Cross River State of Nigeria: A Stochastic frontier Approach. World Journal of Agricultural Sciences. 3(5): 653-658

Jondrow, J., Lovell, C.A.K., Materov, I.S., Schmidt, P. 1982. On Estimation of Technical Inefficiency in the Stochastic Frontier Production Function Model. Journal of Econometrics. 19 (1): 233-238.

Kusnadi, N., Tinaprilla, N., Susilowati,S.H., Purwoto, A. 2011. Analisis Efisiensi Usahatani Padi Di Beberapa Sentra Produksi Padi Indonesia. Bogor (ID): Jurnal Agro Ekonomi. 29(1): 25-48.

Nurmalina, R. 2008. Analisis Indeks dan Status Keberlanjutan Sistem Ketersediaan Beras di Beberapa Wilayah di Indonesia. Bogor (ID): Jurnal Agro Ekonomi. 26(1): 47-79.

Ohajianya, D.O., Otitolaiye, J.O., Saliu,O.J., Ibitoye, S.J., Ibekwe, U.C., Anaeto, F.C., Ukwuteno, O.S., Audu,S.I. 2014. Technical Efficiency of Sweet Potato Farmers in Okene Lokal Government Area of Kogi State Nigeria. Asian Journal of Agricultural Extension, Economics dan Sociology. 3(2):108-117.

Okaye, B.C., Onyenweaku, C.E., Agwu, A.E.s 2008. Technical Efficienct of Small-Holder Cocoyam Farmers in Anambra State Nigeria:Implications for Agricultural Extension Policy. Journal of Agricultural Extension. 12(1).

Pusat Data dan Sistem Informasi Pertanian. 2013. Buletin Konsumsi Pangan No.2 Volume 4. Jakarta (ID):Pusat Data dan Sistem Informasi Pertanian. 